\title{
The Impact of Macro Factors on the Profitability of China's Commercial Banks in the Decade after WTO Accession
}

\author{
Qinhua Pan, Meiling Pan \\ Schools of Economics and Management, Tongji University, Shanghai, China \\ Email: pangh4902@126.com, 15001801112@139.com
}

Received May 2014

\begin{abstract}
Profitability of China's commercial banks has increased significantly since it joined the World Trade Organization (WTO). Constantly advancing of deepening the reform and increasingly fierce of international competition make us to be concerned more about macroeconomic factors. This paper makes an empirical analysis with a panel of 10 Chinese listed banks during the period 19982012 to make a study of the potential impact of external factors may bring to China's capital market. The results confirm that macroeconomic do have a substantial influence to the earning power of commercial banks, according to which some suggestions are made at the end of the paper.
\end{abstract}

\section{Keywords}

Commercial Bank, Profitability, Macroeconomic Factor, Financial Innovation, Risk Control

\section{Introduction}

Since joining the WTO in 2001, most of the Chinese commercial banks completed the shareholding reform and established a modern enterprise system through processes like financial restructuring, the introduction of strategic investors and public listing. In 2013, China’s total banking assets reached 151.3547 trillion yuan, an increase of 119.7557 trillion yuan more than in 2004; Non-performing loans amounted to 592.1 billion yuan, decreased by 1.1255 trillion yuan than in 2004; Return on assets reached 1.27\% (Source: National Bureau of Statistics). Thus, asset size, asset quality and profitability of the banking sector have improved significantly.

With the constantly advancing of deepening the reform and increasingly fierce of international competition, it becomes an urgent task to improve the profitability and enhance the competitiveness of commercial banks. This paper aims at researching on the potential impact of external macroeconomic factors may bring to China's capital market and making appropriate policy recommendations by using theoretical and empirical analysis.

The paper is organized as follow. After this introduction, Section 2 shows the influence factors on China's commercial bank. Section 3 reviews some theories about how macro economy works. Section 4 is the empirical study part. Section 5 presents the policy recommendations and conclusions. 


\section{The Influence Factors on Profitability}

Factors affecting the profitability of China’s commercial banks can be divided into three levels: the micro-level, meso-level and macro-level.

Micro-level factors, namely, bank-level factors, refer to the bank's internal factors, including the terms of asset size, asset quality, capital liquidity, capital adequacy, risk control, operations management capabilities [1]. Since the 1980s, three times of non-performing asset stripping has injected new vitality to China's commercial banks. Business model which focuses not on the asset quality but on the quantity is gradually being replaced by modern philosophy of management. The key issues to improve the competitiveness and profitability of China's commercial banks are to improve risk management capabilities and reduce non-performing asset ratio.

Meso-level factors refer to industrial competitiveness factors. China’s banking Herfindahl-Hirschman Index (HHI)* showed a declining trend, the concentration of total assets declined from 2476 to 1431 in 13 years [2]. These data show that China's banking market structure gradual is developing gradually from oligopoly to monopolistic competition, and industry competition is becoming fiercer and fiercer. In order to maintain market competitiveness of commercial banks, profitability should be enhanced.

Macro-level factors mainly include factors like economic growth, monetary policy, inflation, economic cycle and financial development. From an international perspective, the ever-changing international situation brings uncertain macro environment to commercial banks; domestically, factors such as deepening reform, inflation and overheated real estate market existed in China caused a substantial impact to profitability of commercial banks. Therefore, the study of macro factors affecting the profitability of commercial banks has an important reference significance for not only the correct and comprehensive understanding of the status of commercial banks but also the future direction of China's reform, which is also the focus of this paper.

Some theories on macroeconomic and profitability are as follows:

\subsection{Economic Growth}

First, growing economic promotes consumer and social investment, thereby increasing the demand for bank credit, and banks generate more interest income, thereby increasing profits. Second, economic growth promotes more trading activity, which increases the intermediate business income of banks, and also leads to profits increasing.

\subsection{Monetary Policy}

Quantitative monetary policies affect the profitability of commercial banks by controlling the money supply. Firstly, monetary policy will increase the money supply, which directly increases the available funds of commercial banks, thereby increasing the interest income of bank. Secondly, the increase in demand for bonds raises its price. As we know, there is a reverse relationship between bond prices and interest rates. Higher bond prices led to lower interest rates, which stimulates consumption and increase investment, expand the scale of commercial bank credit, thereby increasing the profitability of commercial banks [3].

Price-based monetary policy, such as lending rates also relates to earnings of commercial banks: the rise of interest rates reduce the number of loans, and loan interest increase, thereby leading to changes in profitability of commercial bank [4].

\subsection{Inflation}

Inflation may affect the profitability of commercial banks in the following ways: It reduces the real income of consumers, making consumers more willing to invest in other financial products that have higher rate of return. Which makes traditional commercial banking business model that takes spread as the main source of income be sorely tested; Inflation will affect fiscal policy and monetary policy. Prudent fiscal policy and tight monetary policy will slow down economic growth, thus reducing profits [5]. Moreover, some theories believe that the impact of inflation depends on whether it has been expected.

\subsection{Financial Market Development}

There are both complementary effect substitution effect between direct financing and indirect financing, and 
therefore the relationship between the banking sector and financial markets are uncertain. Development of financial markets weakens consumers' demands for banks, creating a competitive relationship between them. Meanwhile, there is a certain complementary relationship between banking sector and financial markets because their mutual promotion roles in the development process.

\section{Empirical Analysis}

\subsection{Model}

To study the effect Gross Domestic Product (GDP), money supply growth, loan interest rates, inflation rates and gross stock prices have on Return on Assets (ROA), and to inspect the influence macroeconomic conditions have on the profitability of commercial banks, the following regression model is established:

$$
\mathrm{ROA}_{\mathrm{i}, \mathrm{t}}=\beta_{0}+\beta_{1} \mathrm{GDP}_{\mathrm{t}}+\beta_{2} \mathrm{INF}_{\mathrm{t}}+\beta_{3} \mathrm{M}_{\mathrm{t}}+\beta_{4} \mathrm{R}_{\mathrm{t}}+\beta_{5} \mathrm{LNSTOCK}_{\mathrm{t}}+\mu_{\mathrm{i}, \mathrm{t}}
$$

where, $i$ represents different banks; $\mathrm{t}$ represents different years; $R O A_{i, t}$ is the dependent variable, on behalf of ROA of bank $i$ in period $t ; \beta_{0}$ is the intercept term; $\mu_{i, t}$ is the error term; The remaining variables are explanatory variables and specific meaning are shown in Table $\mathbf{1}$.

Considering the representation, availability and integrity of data, this paper used panel data of 10 China's commercial banks during the period 1998 and 2012, and calculated ROA value by annual reports of these banks. There are four state-owned commercial banks, namely the Industrial and Commercial Bank of China, Agricultural Bank of China, Bank of China and China Construction Bank. There are six joint-stock commercial banks, namely China Merchants Bank, Minsheng Bank, Shanghai Pudong Development Bank, Industrial Bank, Shenzhen Development Bank and China CITIC Bank.

The total market capitalization of stock reflects the level of financial market development. As the scale of China's bond market in the capital market is small, here mainly take into account the level of development of the stock market.

The data of this section are from the Bank Annual Report, the National Bureau of Statistics and the China Financial Yearbook.

This model represents that ROA is explained by GDP, money supply growth, interest rates, inflation rates, total market capitalization of stock and other factors. Coefficients in front of the Arguments represent the degree and direction of influence that independent variables have on the dependent variable.

Through the theoretical analysis, we can see that the coefficient of GDP is expected to be positive; money supply growth is expected to be positive; symbol of inflation rate is expected to be negative; the symbol of Lending rate is uncertain, depending on the sensitivity of the number of loans to interest rates; the Symbol of total market capitalization of stock is also uncertain, depending on the relative extent of the complementary and substitutive effects between financial markets and the banking sector.

\subsection{Descriptive Analysis}

As it can be seen in Figure 1, ROA of China's commercial banks is steadily rising. China joined the WTO in 2001. Therefore, the banking sector subjected to certain shocks, resulting in a relatively low ROA. Then China's

Table 1. Definition of Indicator.

\begin{tabular}{ccc}
\hline Category & Symbol & Definition \\
Bank profitability & ROA & ROA = Net Income/Average Total Assets \\
Economic growth & LNGDP & Ln(GDP) \\
Monetary Policy & M1 & Money supply growth \\
Inflation & $\mathrm{R}$ & Long-term lending rates \\
Financial Market Development & INF & Inflation \\
\hline
\end{tabular}




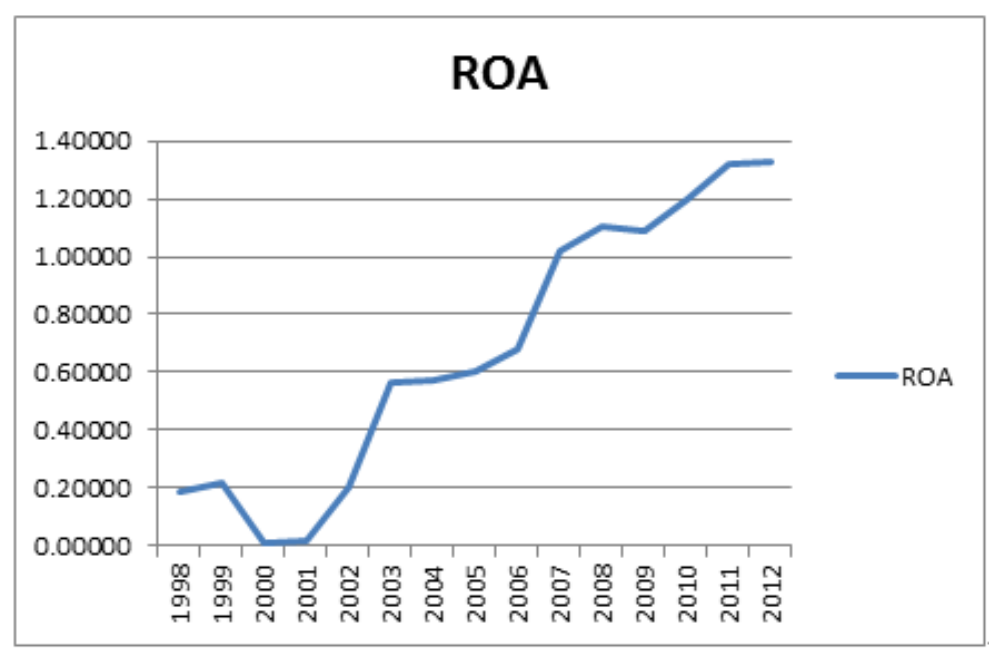

Figure 1. Return on assets of China's commercial bank ${ }^{*}$ Source: Calculated by the Bank Annual Reports.

state-owned commercial banks began a shareholding reform from 2003 onwards, which lead to the increase of return on assets. The ROA reached 1.33 in 2012.

\subsection{Empirical Results}

In this paper, Eviews is used as regressive analysis software. For comparison, we use the natural logarithm of GDP and total market capitalization of stock.

To determine the regression model, first of all, we use F-test to examine varying-coefficient model, variable intercept model and mixed regression model. We get the residual sum of squares S1, S2 and S3 and calculated them separately. The result is F1 $=4.9266, \mathrm{~F} 2=4.269$, thus rejecting the null hypothesis. Therefore, the fixed effects regression with varying-coefficient should be used.

When it comes to the fixed-effects regression and random effects regression, we use the Hausman test. Under the condition that null hypothesis is random effects model, P-value is greater than 0.05 , so the null hypothesis cannot be rejected.

So we take a random effects model at length.

The regression results are shown in Table 2.

From Table 2, we can see that F-statistic is 32.98395, and it has passed the F test at 0.05 confidence level. This shows a significant linear relationship of this model. $\mathrm{R}^{2}$ of random effects model cannot explain the extent of its fitting, therefore it will not be considered. Coefficient values of these variables are in line with economic significance. Where, LNGDP, R and M1 have passed the test of significance, INF is less significant, and INSTOCK is the least significant.

Sign of GDP coefficient is positive, which is in line with expectation. This shows that economic growth has a positive correlation with the profitability of commercial banks, economic growth lead to the promotion of the profitability of commercial banks.

Sign of money supply coefficient is positive, and it is in line with expectations. This shows that the increase in the money supply will enhance the profitability of commercial banks. When the central bank shrinks the money supply, the size of credit will reduce. Commercial banks that take interest income as the main source of income will face a significant decline in profitability. It can be seen from the coefficient that the impact of money supply on profitability of commercial banks is the most obvious.

Sign of loan interest rate coefficient is positive. Hence the rise in loan interest rate will increase the profitability of commercial banks. Because the number of loans is not sensitive to interest rates and loan scale of commercial banks did not reduce so much. The increase of interest income brought by interest rate is more than the loss of loans, resulting in the increase of profitability.

Sign of the inflation rate coefficient is positive, inconsistent with expectations, which shows that the rise in inflation rate increased profits of commercial banks. The author suggests that there are two main explanations: 
Table 2. Random effects model estimation results.

\begin{tabular}{ccccc}
\hline Variable & Coefficient & Std. Error & t-Statistic & Prob. \\
\hline C & -0.059433 & 0.008539 & -6.959847 & 0.0000 \\
LNGDP & 0.004537 & 0.001160 & 3.910503 & 0.0001 \\
M1 & 0.011317 & 0.006024 & 1.878670 & 0.0623 \\
R & 0.001854 & 0.000308 & 6.016363 & 0.0000 \\
INF & 0.000381 & 0.000240 & 1.588467 & 0.1144 \\
LNSTOCK & -0.000208 & 0.000746 & -0.279193 & 0.7805 \\
\end{tabular}

On one hand, the decisions of residents about investment and savings are based on their nominal income. Inflation increases nominal income, enhancing the wishes of residents to invest and save, thus increasing the profits of commercial banks; on the other hand, Inflation is expected and commercial banks adjust their decision according to the expected inflation. Therefore, they made profits.

Stock market capitalization is the least significant because China's financial market is not perfect and funding needs are met mainly by financial intermediaries.

\section{Conclusions}

This paper makes an empirical analysis with a panel of 10 Chinese listed banks during the period 1998-2012 to make a study of the potential impact of external factors may bring to China's capital market. The model takes Return on Assets as a dependent variable, and takes GDP, inflation rate, money supply growth, interest rates and total market capitalization of stock as explanatory variables.

The results confirm that macroeconomic do have a substantial influence to the earning power of commercial banks. Economic growth, inflation, interest rates and money supply growth have positive correlations with bank profitability, while total market capitalization of stock has a negtive correlations with bank profitability. Among these selected macroeconomic variables, influence of money supply growth is the most obvious.

Thus this paper put forward three proposals:

\subsection{Accelerate Financial Innovation and Diversification Strategy}

Financial innovation means the change of existing financial system and the addition of new financial instruments which are to obtain potential profits that existing financial institutions and financial instruments cannot be achieved. Financial innovation can reduce the risk of commercial banks; reduce costs and improve economic efficiency; guide the flow of funds and optimize the market allocation of resources [6]. China's commercial banks should accelerate the pace of financial innovation and create diversified financial products to meet consumer demand so as to remain invincible in the competition.

\subsection{Develop Intermediary Business}

China adjusted the macroeconomic several times through tighter monetary policy, which had a negative impact to the profitability of commercial banks. To change this passive situation, China's commercial banks should develop intermediary business. Increasing the profitability of the intermediary business can change the single profit model that takes spreads as the main source of income. Thus, banks can better cope with tighter monetary policy and better respond to fluctuations in macroeconomic conditions.

\subsection{Improve Ability of Risks Control}

When economic growth slows, the profitability of China's commercial banks has significantly decreased. To deal with this adverse macroeconomic condition, commercial banks should improve ability of risk control; reduce the rate of non-performing assets; improve asset quality and improve asset utilization efficiency. 
With the further development of financial innovation, China's commercial banks will face more risk. At present, the risk control concepts of China's commercial banks lag behind and architecture of risk control system is inadequate, which caused the damage to profitability of commercial banks. Banks should improve risk control capabilities and establish a sound risk management system so as to reduce the impact of adverse factors, thus improving profitability.

According to the theory and empirical analysis, external macroeconomic may bring some potential impact to China's capital markets in the future. For example, when the economic downturn, credit will be pulled back, thus having a huge impact to China's commercial banks earnings. In order to actively respond to changes in macroeconomic conditions, and turn the adverse conditions to favorable conditions, commercial banks should accelerate financial innovation, improve ability of risks control and develop intermediary business. Thus they can improve the profitability and competitiveness.

\section{References}

[1] Yang, X.Q. (2010) Bank Profitability Based on the Bank’s Portfolio Theory. Dalian University of Technology.

[2] Ding, L.F. (2010) Research on the Impact of China’s Commercial Banks Profitability Factors. Shanghai International Studies University.

[3] Cheng, Y.W. (2013) Effects of Chinese Monetary Policy on the Earnings of Commercial Banks. Fujian Normal University.

[4] Zhang, L. (2012) Impact of Tight Monetary Policy on Commercial Banks’ Profitability Analysis. Accounting Monthly, 2, 24-26.

[5] Liu, S. (2011) Impact of Inflation on China’s Commercial Banks Profit Model. Jilin Financial Research, 4, 21-24.

[6] Wang, Z.X. (2014) Analysis of the Impact of Financial Innovation and Risk Control Measures. China foreign Investment, 4, 45. 